\title{
Past and Future in the construction of Communal identity: Collective Memory and Mythical Narratives
}

\author{
Christoffer Kølvraa \\ Aarhus Universitet
}

This article relates to the question of whether or to what extent identity is wholly constructed through language by engaging in a discussion of how the use of the past enters into the construction of communal identity. It argues that in order to understand why collective memory and the mythical narrativisation of the past which it frames are such powerful elements in the construction of collective identities, it must be distinguished from the science of historiography. But neither can collective memory be thought of as a communal analogue to the individual mental process of remembering. Rather it is a specific kind of discourse whose subject-position is endowed with a number of distinct privileges (different from those in the discourse of modern historiography) and through which a community can approach and articulate its past in mythical narratives whose 'validity' in fact has little to do with the extent to which they mirror 'historical reality'.

The discussion about whether or to what extent human identity both at an individual and at a collective level - is wholly constructed through language, entails a vast array of controversies and fault lines. A dominant one has been the discussion about the 'plasticity' of reality in relation to the force of symbolic inscription; the degree to which the world - and ourselves in it - simply yields to our language about it, and thus to the interests, biases and power hierarchies ingrained in language and language use at any given time. In the field of history this debate has centred on the issue of 'collective memory' and its associated term 'mythical narratives'. In the classical teleological idea of history, the past could be mined for the truth about the present. The initial scandal of such notions as 'collective memory' was that it inverted this causal relationship, claiming that it was to a large extent the power relationships and needs of the present, which determines how the past was imagined - and that the historical sciences where indeed part of this dynamic. 


\section{Christoffer Kølvraa}

In what follows I will align myself with the constructivist view that the present identity of a community is certainly not simply produced by its history, but is a construction which involves - in a central way the correlate construction of adequate narratives about the communal past. But I will also argue that it is nevertheless too simplistic to claim that the historiography and the narratives of collective memory are therefore two sides of the same thing. Historiography is not simply an institutionalised version of collective memory, nor is collective memory simply 'bad history'. In order to understand why collective memory and the mythical narrativisation of the past which it frames, are such powerful elements in the construction of collective identities, it must be distinguished from the science of historiography. Even if often intermingled, the (ideal-typical) differences nevertheless discernable between collective memory and historical science, allows for a clearer view of the specific practices, privileges, and functions that myth and memory has in relation to the symbolic construction and maintenance of community.

I will furthermore argue that collective memory should not be thought of as a communal analogue to the individual mental process of remembering, but rather as a specific kind of discourse, whose subjectposition is endowed with a number of distinct privileges (different from those in the discourse of modern historiography) and through which, a community can approach and articulate its past in mythical narratives whose 'validity' in fact has little to do with the extent to which they mirror 'historical reality'. Myth - understood here as the narration of the communal past, present and future utilising the privileges of a collective memory discourse - is not to be understood simply as a 'primitive', 'degraded' or 'amateurish' form of historical recounting, but as form of political narrativity which deliver legitimacy to both present power structures in a community and to future political aims.

First, however it is necessary to discuss the connection between identity and the narration of the past in more general terms. Here I rely primarily on the thinking of Paul Ricoeur.

\section{Narrating the past and identity}

In Ricoeur's thinking temporality and narrative are connected at a fundamental level of the human experience. The foundational claim in Ricoeur's theory is that narrative is not a representational form that can be imposed on reality; it is an ontological condition of social life. 
It is the way human subjects comprehend temporality. As Ricoeur puts it: "Time becomes human to the extent that it is articulated through a narrative mode" (Ricoeur 1984:52). Events are therefore ascribed a specific meaning through emplotment. The act of emplotment consists in the integration of the episodic dimension of narrative (the dispersal of different events in a chronology), with the configural dimension (the story as a whole, with unified point or theme to it). "In short, emplotment is the operation that draws a configuration out of a simple succession" (Ricoeur 1984:65). And conversely an event "only get its definition from its contribution to the development of the plot". (Ricoeur 1984:65). What we have is a past (the events) that only becomes 'our (hi)story' (a narrative) through the intervention of emplotment, or as Ricoeur would have it "(...) a prefigured time that becomes a refigured time through the mediation of a configured time." (Ricoeur 1984:54).

The fundamental point here is that when temporality is given the form of narrative, this is a way of handling contingency. The passing of time itself does not deliver any kind of stability or final meaning, simply because it is a process which never stops or concludes. As Barbie Zelizer puts it: "Time undoes its ability to shape communities by not being able to stop shaping them" (Zelizer 1995:222). Emplotment is the operation which "(...) inverts the effect of contingency, in the sense of that which could have happened differently or which might not have happened at all, by incorporating it in some way into the effect of necessity or probability exerted by the configuring act"'(Ricoeur 1992:142). Narrative in other words domesticates the temporal onslaught of unexpected or seemingly meaningless events by ascribing them a teleological necessity, not simply by constructing obvious causal links, but by treating them as twists and turns in an unfolding story, which by its very form carries the promise of a meaningful conclusion; a unified point or morale. Events might then very well keep their status as unexpected or 'turning points' but they are so within the narrative structure and as such can still be considered meaningful in relation to the plot of the story. Narrating, quite simply, is not about denying change, but about domesticating it, giving it a direction and a point. Temporal changes, in other words, are stripped of their contingency, by transforming them into a (teleological) development of a unified plot.

Ricoeur's ideas about identity emerges directly form his theory of narrative. The identity of the subject is constituted as that of a character in a story. This means that "Narrative constructs the identity of the character (...) in constructing that of the story told. It is the identity of 


\section{Christoffer Kølvraa}

the story that makes the identity of the character" (Ricoeur 1992:147148). Ricoeur's fundamental claim about human identity, our sense of selfhood (Ipseity), is that it is constituted as the result of a narrative, as the endpoint of an emplotted development. And as such that it is more and different form the identity of things (Idem) which is simply constituted as the identity of being permanently identical to it-self. To be a thing is to be identified and re-identified as the same by a range of unchanging properties. To be human is something more; the identity of the human subject has a narrative dimension. The subject is characterised by having what Heidegger called Dasein, the ability to pose the question 'who am I?' (Ricoeur 1991:75). To examine ipseity, Ricoeur claims, is;

[T]o look into the nature of the question to which the self forms a response (...). This question is the question who, distinct from the question what. It is the question we preferentially pose in the domain of action when, in searching for the agent, the author of the action, we ask, 'who did this or that?'

(Ricoeur 1991:75)

The distinction between the question of identity in terms of 'who' and in terms of 'what' is central here. In fact it is Ricoeur's main critique that these two are often mixed together in discussions of identity. The problem in such discussion, he contends, is that the question of ipseity 'who?' is answered in the mode of identity that is proper to the question 'what?'. The fulfilling answer the question of 'who' (are you?) is he claims, drawing on Hannah Arendt, "to tell the story of a life" (Ricoeur 1988: 246). This translates into three assertions made by Ricoeur: “a) knowledge of the self is an interpretation, b) the interpretation of the self finds narrative, among other signs and symbols, to be a privileged mediation; c) this mediation borrows from history as much as fiction, making the life story a fictive history or (...) a historical fiction (...)" (Ricoeur 1991:73).

Ricoeur's idea of identity are formulated in relation to the individual, but as Ricoeur himself repeatedly claims, the main points however does correspond equally well with the identity of communities.

Fundamentally it seems viable to claim that also when speaking of collective identities, their temporal dimension is in fact a narrative one. From the plethora of events and changes that make out the past of any community, meaning is drawn or rather formed through the 
construction of a narrative. The actual past is of course always more than the narrative. The configuration of a temporal succession in to a narrative involves eliminating the ambiguity of any event emplotted - suppressing alternative interpretations than that which conforms to the narrative plot. But it also involves a basic selection of at the level of events. The narrative configuration of the past will always involve simply disregarding some events or developments as irrelevant or arbitrary. Relating to the past as a meaningful narrative does in other words not only entail remembering certain events in a certain way, but also the disregarding or forgetting of a range of others. The elimination of contingency through narrative comes then at the price of what we might call the full complexity of the past. The suppression of contingency in narrative results in the suppression of contingency in its characters. The narrative construction of identity - positing the community as the result of a meaningful temporal process - serves to imbue the present constitution of the community with an air of necessity and naturalness. But if narrative is to fulfil the function of eliminating contingency in identity, then its own constructed and therefore contingent nature must be denied. It must appear exactly not as a specific narrative of the past (that is one among others), but as the Past itself: singular, indisputable and incontestable. Hayden White also makes this point by distinguishing "between a historical discourse that narrates, on the one side, and a discourse that narrativizes, on the other; between a discourse that openly adopts a perspective that looks out on the world and reports it and a discourse that feigns to make the world speak itself and speak itself as a story"(White 1980: 6-7). The construction of identity relies, in White's terminology, not only on a narration of the past, but on its narrativization. I contend that such narrativisation and its connection with a specific community is what becomes available when the past is articulated in what might be called the discourse of collective memory and that this has to do with the specific privilege enjoyed by the speaking subject here, or in a Foucauldian terminology with the mandate tied to the subject-position of this discourse. The crucial questions thereby shift from a focus on ontological foundations to one on the actual discursive practices. One is no longer preoccupied with the question of what collective memory is (as some kind of object in the world which either exists or not), but instead in how it is done (as a discursive praxis which produces its own effects and consequences irrespective of its ontological status). 


\section{Christoffer Kølvraa}

The privileges of the first person plural: The past as History and Memory

Treating collective memory as a specific kind of discourse, therefore not only reorients the investigation towards the kind of privileges enjoyed by the narrating subject, but also allows one to cut across one of the central unresolved issues of the very concept of collective memory. The very concept itself has almost from the onset come under attack as nonsensical by scholars who point out, that memory is a mental operation undertaken by individuals in relation to their unique experiences and as such cannot be collectivised unless one is ready to postulate the existence of some kind of collective mind. At the onset however, the idea of a collective or social dimension to memory did not so much involve the postulate of shared memory content or indeed of a collective process of remembering, but rather simply pointed out the social context in which (individual) remembering took place and the impact of this context on what was to be remembered.

In the seminal works on 'the social frameworks of memory' by Maurice Halbwachs the central claim was that memory is selective, and that the selection of what was to be remembered and what was to be forgotten, was by no means an autonomous decision taken by the individual. It was determined by the social frames within which the remembering took place; i.e. by the groups of which the individual was a member, be it the family, the nation or the religion (Halbwachs 1992:38, 55-54, 167-189). The collective level in Halbwachs is more than anything simply the supplier of schemata for what should be remembered, whereas the content of memories remains individual and personal (Warring 1996). In this vein James Young has argued, that individuals cannot "share another's memory any more than they can share another's cortex. They share instead the forms of memory, even the meanings in memory generated by these forms, but an individual's memory remains hers alone" (Young 1993: xi). There in this case, as Reinhardt Koselleck has likewise recently argued, no such thing collective memory. As any memory relies on an individual experience, there are only collective conditions for remembering (Koselleck 2003:58).

This attitude wards of any implicit or explicit positing of collective mental faculties akin to the long discredited ideas of Völkerpsykologie (Wilson 2005). But the consequence is that the subject of memory is always in the last instance an individual. The only place left for a concept of collective memory, is as a simple multiplication of such remembering 
individuals. This ties any remaining idea of collective memory to groups of people that where all really and personally 'there'; to those often few surviving Zeitzeuge of a certain event (Markovits \& Reich 1997:16). In this vein it makes sense to talk of the collective memory of the Holocaust, only if it is the collective of Holocaust survivors one refers to, and certainly not as a collective memory of a nation or a continent. Not only is the dissemination of memories in spatial terms excluded, i.e. that the nation as a collective can remember what strictly only happened to a part of its members, but the dissemination of memories between generations is equally ruled out. This means that collective memory falls away (or turns into history if one follows Halbwachs (Crane 1997:1377)) with the passing of each succeeding generation.

In the end then we may have warded of the inconsistency of implicitly postulating a collective mind as the foundation of collective memory, but the price seems to be that the concept is emptied of most of its analytical potential in relation to a world in which nations are routinely referred to as having forgotten, and where the exclamation 'Remember!' or 'We must never forget' - for example in referring to the Holocaust - is often directed at audiences, most members of which are simply too young for this possible in any strictly real or individual sense.

As Paul Connerton has rightly pointed out, if collective memory is to be a useful concept it must be liberated for the tight connection to Zeitzeuge. It must include an idea of how memories can be passed on between generations, in such a way that members of collectives have a range of memories that strictly speaking are not their own (Connerton 1989:36-40). The solution that Connerton and many others have sought is to think of memory as having a materiality that exists independently of the individual and his lifespan. The focus then turns to commemorative rituals, monuments and traditions. Most famously in this vain is Pierre Nora's extensive survey of places where collective memory is anchored, the so called 'liex de memoire' (Nora 1989). As Kerwin Lee Klein critically remarks however, this approach might escape any talk of a collective mind, but instead "we enter a new age in which archives remember and statues forget" (Klein 2000:136). The discussion on where to locate the remembering capacity is in other words by no means dodged or solved by shifting the focus to the materiality or 'texture of memory' as a central work in this vein is entitled (Young 1993). It would seem that we are trapped in a choice between using the concept in a severely limited or in a thoroughly inconsistent way. 


\section{Christoffer Kølvraa}

The fact is however, that this dilemma only arises because collective memory is thought of in term analogous to the individual mental process of recalling earlier experiences in the mind. Actually this is a very limited and 'technical' view of memory even at the individual level. It focuses solely on memory as an 'information-retrieval' process requiring a certain kind of 'hardware' (the individual human brain). But as already Kierkegaard understood, what is crucial about memory - in the sense that it is employed in speaking about 'collective memory' is less the facts retrieved or the means of their retrieval, and more the distinct kind of relationship which the remembering subject maintains to that which is remembered. Kierkegaard distinguishes between recollecting (the Danish original of which is erindre) and remembering, (which in Danish is huske). A central claim is that:

To recollect [erindre] is by no means the same as to remember [huske]. For example one can remember very well every single detail of an event without thereby recollecting it. Remembering is only a vanishing condition. Through memory the experience presents itself to receive the consecration of recollection. (Kierkegaard 1988:9)

The distinction between recollection and remembering is less sharp in English, but in Danish the terms 'huske' and 'erindre' in fact still retain the distinct connotations that Kierkegaard emphasises. 'Huske'/ remembering is simply information retrieval and regard recalling the past event in as much detail as possible. But as Kierkegaard states 'erindring'/recollection is something much more than remembering the details. It is a consecration, a deep emotional connection established to something past. It involves the subject's deepest reflection about his past in relation to his present existence (Kierkegaard 1988:10). When recollecting what matters is the meaning that the past events holds for the remembering subject, and thus their ability to signify moral lessons, crucial personal developments or choices with profound consequences. Recollection is about the 'subjective past'. It is not about the correctness of the historical details, its function is not to render precisely how things really were, but to speak of what they meant and mean to the remembering subject. Recollection as a relation to the past in other words marks out the subject of the recollecting activity, and privileges it above the objects remembered. The privilege of recollection then is akin to those of the literary genre of autobiography, in which, as Torben 


\section{Past and Future in the construction of Communal identity ...}

Weinreich has pointed out, the subject's account of the past becomes immune to factual critique:

Others may claim from the outside; I too saw it happen and you are mistaken. But such protests have no legitimacy, because no one else has 'internal access.... to knowledge about the I that the narrative is about' $(\ldots)$. The I-narrator then has not only a subjectivity privilege but also a sovereignty privilege, not only access to but the exclusive right to the I.

(my translation, Weinreich 1996:102)

It is in essence my suggestion that collective memory should be treated as a form of discourse akin to autobiography, and that crucially the very term collective memory is in fact something of a misnomer. The kind of relationship to the past that is articulated in collective memory is actually that which Kierkegaard termed recollection/erindring. What we mean when speaking of collective memory is in fact the articulation of past events in the mode of recollecting them, and in a way which posits the community as the subject thus contemplating its meaning through the recalling of its past. Whether or not particular members of the community actually experienced the collectively remembered events matters less. Just as the community only exists in an imagined form, so too does its collective past. Imagined communities are, as Benedict Anderson has argued, composed not simply at the congregation of current members, but as an purely discursive construction of communion including not just present members who will never actually meet and interact, but also members long dead and those yet to be born (Anderson 1991). In collective memory we speak in the name of and in the voice of this extended imagined community. The privilege and mandate enjoyed by the subject-position from which one speaks in a collective memory discourse, therefore potentially transcends that of simply representing the community (being authorised to speak on its behalf - in its name), and involves the 'autobiographical' privilege of speaking its voice, of exclusive internal access to the unique experience of the remembering 'We'. It is so to speak a transfer to a collective level of the privilege afforded the subject who has not only witnessed something, but who is recounting the autobiographical story of what it meant to the subject. Here no exterior voice or critique has any force, nor is it necessary that the narrative validates itself in relation to some empirical or otherwise established 'objective' foundation of how it 'really' was. Collective 


\section{Christoffer Kølvraa}

memory is a species of Kierkegaard's 'recollection/erindring' because it is about the emotional impact of a past event rather than about its factual reality and as such it unashamedly privileges the 'internal' subjective relation to this experienced past. But the prime achievement of collective memory discourses is that despite moving from a witnessing ' $I$ ' situated in time and space, to a both spatially and temporally extensive 'we', these autobiographical privileges is nevertheless retained. If as Kierkegaard argues the individual can remember without recollecting (recalling information without any particular emotional impact), the members of a community can - when articulating their common past as collective memory - recollect without remembering. The emotional and existential significance of certain past events for the community can be discursively marked and thus transferred to generations which did not experience them. The past events collectively recollected cease to be simply more or less factual accounts of past events, and become in their own right the resource of moral metaphors and sacred values around which community membership is constituted and bordered. In the last instance a certain relationship to or interpretation of past event might therefore emerge as a continual moral imperative; To be German is to accept the moral meaning and burden of a particular collective Holocaust memory, also for those generations lucky enough to be born after the Second World War. This of course does not mean that collective memories do not change or cannot be refuted by those who might disagree with the communal imperatives that they underpin. However their change or critique are rarely simply a consequence of new historical knowledge coming to light. The struggles over collective memory are often masked political struggles about the moral infrastructure of present societies, rather than about the factual reality of past ones. In this light for example the gradual breaking up of a certain simplified heroic memory of Danish resistance during the German occupation, has less to do with discoveries made in archives, but should rather be understood in terms of a radically changed contemporary context in which stereotypical enmities and essentialised images of the (German) Other have become both morally and politically unviable. Indeed such a point seems further supported by the fact the traditional heroic narrative of Danish resistance is maintained most forcefully by political forces on the right for whom it is opportune to establish a parallel to a contemporary stereotypical and essentialised (Muslim) Other. 


\section{Past and Future in the construction of Communal identity ...}

To grasp the specific nature, privileges and effects of a collective memory discourse, it is as such crucial to insist that such a discourse is not identical to that of historiography, and not even 'bad historiography'. Of course what is here described under the headings of collective memory and historiography, is to a large extent ideal types; heuristically constructed outer points on a continuum. Any historical account, statement or work will most often contain components of both. Nonetheless their differentiation remains important and instructive. As argued above a place to start such differentiation would be in pointing out how collective memory privileges the subjective and emotional, disallowing outside voices and producing ultimately moral imperatives, whereas historiography upholds the (always unrealised) ideal of a disinterested objectivity, open to legitimate critique and revision. As Kerwin Lee Klein puts it: "If history is objective in the coldest hardest sense of the word, memory is subjective in the warmest. In contrast with history, memory fairly vibrates with the fullness of being. "(Klein 2000:130). Historiography therefore ideally maintains a distance to its subject matter. 'History' as Ricoeur has pointed out actually has two distinctly different meanings; it is on the one hand a literary activity - the writing of historiography, but on the other it is also 'what men do and suffer' the actual temporal mode of human existence (Ricoeur 1988:274). Whereas historiography marks this difference - it is a literary account of someone else's history, their lived experience - collective memory hides it, reporting the experiences of past individuals as 'ours'. Historiography is the critical appraisal of the memory of others - in the form of the traces or sources left by the past - through the application of the methodology of the historical science. The historian relates to past events and experiences from a distance - he is external to them and it is this disinterested externality which is believed to guarantee scientific objectivity. But it also means that the historian does not have the privileges of subjectivity or sovereignty. Indeed the entire methodology of historiography serves to codify a universal framework for critiquing the historical interpretation of the past. The point is that in historiography any interpretation of truth may be legitimately challenged if this critique adheres to the rules of historiographical methodology. No such legitimate position of contention exists in memory. Where in historiography the historian interrogates memories that are not his own, i.e. relate to witnesses, and are subject to a codified form of legitimate critique by his peers, in memory all these roles or positions collapse in to 
one. The collective is at once the witness, the interpreter and the validator of its past. Whereas historiography in marking out the difference between the lived experience examined, and the literary work of historiography as an interpretation of this object, unavoidably also marks the existence and legitimacy of alternative interpretations, collective memory makes no such concessions. This of course does not mean that there cannot or does not exist different memories about the same events, but rather that there is no framework for their comparison; each is sovereign in its own right. In terms of Haydn White's distinction between narrating the past and narrativising it, the lack of interpretative distance drives the discourse of collective memory towards a narrativising of the past. When the interpretative distance - and thereby the existence of valid alternative interpretations - is denied, the resulting narrative no longer express a certain agency acting behind it construction, but seemingly flow naturally from the past itself.

But furthermore collective memory actually does not treat the past as past at all. It does not enquire into the fascinating strangeness of earlier times, rather its point is to assert a fundamental similarity between past events and present conditions, because the past events in memory serves only to illustrate moral principles that are beyond the particular context of their historical illustration. The function of memory in other words is to speak of the moral universals of good and evil, rather than interrogate the differences between past and present realities. It relates therefore to past events through a fundamental lack of historicity:

Collective memory is in a crucial sense ahistorical. (...) Historical consciousness, by its nature, focuses on the historicity of events - that they took place then and not now, that they grew out of circumstances different from those that now obtain. Memory, by contrast, has no sense of the passage of time; it denies the 'pastness' of its objects and insists on their continuing presence.

(Novick 1999:4)

This does of course not mean that memory does not situate that which is remembered in the chronological past, but that the events of memory is not conceived of as 'belonging' to another time. Their emotional impact on the remembering subject resurrects them and make them continually relevant for moral orientation even in a time far removed and fundamentally different from that of their occurrence. 
Past and Future in the construction of Communal identity ...

Collective memory is as such a type of discourse which entail substantial privileges for consuming and instrumentalising the past, and which is therefore in fact most often not concerned with the past as past. It consists rather of articulations whose real object and function is to speak of the present of community, to reiterate certain fundamental values and ideals in the guise of recollecting its past experiences, and ultimately to employ these privileges of communal recollection to legitimate present and future political choices. The concept of political myth would then designate the kind of narrative which operates within the privileges of collective memory, and whose emplotment of a communal past, present and future realises their political potential in specific forms.

\section{Political Myth: Narrating past, present and future}

Myths, as I will conceptualise them here ${ }^{1}$, are historical narratives, but their strength does not - as is the case in historical science - rest only on a claim that they truthfully recount 'what really happened'. Situated within the discursive framework of collective memory, mythical truth is moral, rather than empirical truth. More than anything, myth claims what Bruce Lincoln calls authority, which is a kind of validity engendered by the fact that they tell the paradigmatic truth (Lincoln 1989:24). Their narrative produces - as Clifford Geertz remarked about religion (Geertz 1973:93) - simultaneously a 'model of' and a 'model for' the world. Myth narrates the beginning of a world - the moment of foundation. But the mythical narrative flows from the origins to the present and beyond. The ideological function of myth is to promise us 'a conclusion' to the community's narrative identity in the form of a future utopian horizon.

Political myths are cosmogonic narratives - they recount the origin of the communitarian order and co-existence: the founding events (Ricoeur 1987:273). In archaic myths this regarded the creation of the world out of some prior primordial chaos or darkness, often through the activities of Gods. Political myths share this basic narrative structure but regard only the creation of a certain political community, nevertheless often still through some radical break with a 'dark' precommunity history. The story of origins therefore renders what is considered to be the community's fundamental and eternal grounding principles or characteristics. It separates the sacred and the profane, its narrative tells which values and principles are to be forever honoured, 


\section{Christoffer Kølvraa}

and what is to be shunned and avoided at all costs. The first moment of the mythical narrative is therefore the community's emergence from a pre-communitarian chaos (Bottici 2007:121-122). The community is brought into existence, often by the heroic intervention of select 'founding fathers, whose political ideas are subsequently elevated to ideal typical visions of the essence of communal moral order. The foundation is not a 'historical' but a recollected event, which thus in a moral sense sets the stage for political legitimacy and hierarchy also in the present. Crucially the foundation is always 'incomplete'. The reality of the subsequent community is never a mirror image of the Fathers vision, but is found yet to be lacking. It is in this sense that myth produces a paradigmatic image of community, an image of how it 'should be' - but is not yet. It is this element of incompletion of conclusion only yet to come - which drives the narrative forward from the origins to the present and beyond. Myth tells the story of how community came to be, but is also a story of how it is yet to become. The foundation is not narrated as a full constitution but as the beginning of a political project.

In this understanding of political myth there is no longer any strict division between 'foundation myths' that concentrate on origins, and 'eschatological myths' that propose a future utopia, as for example Henry Tudor suggests. Tudor believes that the former validate the given order by grounding it in history, whereas the latter challenges the contemporary order by contrasting it to a utopian alternative (Tudor 1978:305). Political myths as they are understood here always involve both a cosmogonic and an eschatological dimension, because they do not just paint a contrast to a pre-communitarian chaos, but also point towards a utopia in the future. The duality here is not either between past and present (foundational myths) or between present and future (eschatological myths), but between past (chaos) and future (utopia). The difference between the past and the future can be understood as the fundamental dichotomy in myth and expresses as such what Mirceau Eliade saw as the central mythical differentiation between the sacred and the profane (Eliade 1954). Myth therefore is in fact a narrative recounting three 'times'; there is the past time of chaos - a profane time before history in the form of the everyday life and political pursuits of the community began. There is the future time of utopia - a sacred time of such full and effortless harmony that history here will have come to an end. But crucially there is suspended in between these two the mundane time of contemporary society. It is this mundane in-between 
which is the operative realm of myth. The function of myth is precisely to deliver a grander narrative framing of mundane pursuits - to stage everyday political choices as the site of an epic standoff between chaos and utopia. Myth therefore does not exist apart from or behind the immediate sphere of political activity; it is present here through what Hans Blumenberg called 'the work on myth' (Blumenberg 1985) Through a constant reiteration of its basic plotlines, configurative themes and character cast, the present is linked to the founding events and to the utopian resolution (Bottici and Challand, 2006:316). By imposing the 'scenography' of myth on mundane political problems or priorities these become more than what is entailed in their practical or immediate benefits: they are filled with the moral odour of conclusions and emerge as either decisive steps on the road to utopia, or dangerous signs of the community 'slipping backwards' towards chaos. This of course does not mean that the work on myth entails recounting the narrative in totality in every political discussion. Speakers instead make use of certain 'clues'; key words, configurative patterns of events or themes that signal to the community members that the myth is present. Jörn Rüsen calls this the rhetorical deployment of 'narrative abbreviaturen' (Rüsen 1994:11). Reflecting on Rüsen's concept, Klaus Grosse-Kracht however suggests that the art-historical concept of Pathosformlen might better capture the dynamic through which such rhetorical deployment not only refers to a narrative, but in doing so infuses an otherwise mundane matter with moral weight and pathos (Grosse-Kracht 1996:28). And as Chiara Bottici convincingly argues, the infusion of pathos has to do with a feeling that things have significance, rather than simply meaning. The primary function of myth is not simply to make the world intelligible, but to infuse certain choices or objects with significance (Bottici 2007:122127). By significance Bottici means that when something becomes part of the grand trajectory between chaos and utopia, it ceases to be just another object which we 'know what is', and becomes invested with emotional value, it becomes a site of moral meaning.

As already indicated by Ricoeur the narrative form is in fact well suited for such an endeavour. Narrative not only unites a temporal succession by a common plot but drives this plot towards a unified conclusion; a totalising meaning of the entire sequence of temporal progression. As Hayden White has argued this has a number of interesting implications when the narration presumes to be recounting real events. According to White the problem with narrating history is that history as the eternal succession of events in the world does not 


\section{Christoffer Kølvraa}

end, but narrative as a form must end - it must at some point conclude (White 1980:26). Whereas earlier forms of historical writing, such as chronicles or annals, either have no central subject which unifies the events listed or have no conclusion but simply terminate, the writing of history as a narrative must have both a central subject (to whom history happens) and a conclusion (where history seemingly stops happening) (White 1980:24). White's central insight is that to conclude a historical narrative one must exit the mode of recounting different events and make a moral judgement which derives a lesson from the totality of events: "The demand for closure in the historical story is a demand, I suggest, for moral meaning, a demand that sequences of real events be assessed as to their significance as elements of a moral drama" (White 1980:24). Since history itself does not stop, this moral meaning is a consequence of the narrative form rather than of the events recounted. And thus the attraction of the narrative form is derived from a desire for such conclusive meanings in a world which does not itself offer them: "[the] value attached to narrativity in the representation of real events arises out of a desire to have real events display the coherence, integrity, fullness, and closure of an image of life that is and can only be imaginary" (White 1980:27). Mythical narratives trade politically on this desire for narrative conclusion and for the total moral meaning that it promises. It does in other words not only constitute the community's identity as a narrative identity, as the identity engendered by being the central subject in its story, but postpones the conclusion of this communal narration into a utopian future, investing this future therefore with the desire for a complete and harmonious identity, for a world vibrating joyously with a totality of meaning and order.

The extraordinarily forceful combination of memory and myth in the construction and maintenance of community, can then be understood to be the combination of a privilege to speak undisturbed about the moral meaning of the past (tied to the subject-position of a discourse of collective memory), and the progressive narrativity of a mythical trajectory entailing the construction of a utopian closure or conclusion of total clarity, stability and meaning. One regards the status and the mandate of the narrator, the other the narrative's emplotment and trajectory. If collective memory is therefore what secures the conditions of possibility for such a subjective, yet collective, appropriation of the past, then myth is the narrative form which gives it direction and ties it to actual present and future political choices through what Blumenberg calls 'the work on Myth'. 
Past and Future in the construction of Communal identity ...

\section{Concluding remarks}

I have argued here that myth and memory are central in understanding the construction of community, but that the force of such collective appropriations of the past should not be accounted for by constructing a strict analogy to the mental processes of individual memory as psychical information retrieval. Collective memory is a discursive structure and is transferred as such from individual to individual and from generation to generation. The rules which govern its emergence, modification and disappearance are those of discourses, not those of the human brain's abilities to store and retrieve information.

But to claim that collective memory is a social construction of language is by no means to deny its power. On the opposite it is by treating it as a specific kind of discourse that the manifest privileges enjoyed by communal narrators become fully visible. As argued the primary among these is the privilege of sovereignty akin to the one enjoyed by the narrating ' $I$ ' in the literary genre of autobiography. Whereas the discourses of historiography entail a subject-position for the critic and a set of rules for legitimate critique, the autobiographical 'we' in collective memory is sovereign and unchallengeable as it recollects past events in ways validated primarily by the moral and emotional needs and preferences of the community itself.

If these privileges are what secures the narrator a superior and to a large extent immune position for articulating the communal past, then myth is to be understood as the political instrumentalisation of these privileges; as the narrative framework through they are put to work in the legitimation of concrete political choices and aims. Even if fundamentally a narrative about the foundation of community, the original values identified by myth in the emergence of the community are transferred to the present and installed as the moral codes of present communal life. The political choices of the present find in myth a grander frame and therefore a deeper legitimacy than that established by the immediate gains and advantages of particular policies, because myth ties them into narrative trajectory toward a utopian future.

To understand how the construction of community trades on articulations of a common past, it is therefore crucial to appreciate both the status of the subject-position in a discourse of collective memory, and the utopian trajectory of mythical narratives, because one in essence is the foundation for a political potential, realised - in various specific forms - by the other. 


\section{Christoffer Kølvraa}

\section{Notes}

1 The concept of political myths has long been present in the social sciences, but, as Chiara Bottici and Benoît Challand, point out there is, despite an ever-growing literature, no consolidated theoretical framework on political myth (Bottici \& Challard 2006:316).

\section{Bibliography}

Anderson, Benedict (1991 (1983)). Imagined Communities, Verso.

Blumenberg, H. (1985) (1979)). Work on Myth, Cambridge, MA: MIT Press.

Bottici, Chiara (2007). A Philosophy of Political Myth, Cambrigde: Cambridge University Press.

Bottici, Chiara \& Challand, Benoit (2006). Rethinking Political Myth: The Clash of Civilizations as a Self-fulfilling Prophecy, European Journal of Social Theory, 9, 3: 315-336.

Connerton, Paul (1989). How Societies Remember, Cambridge: Cambridge University Press.

Crane, Susan (1997). Writing the Individual back into Collective Memory, The American Historical Review, vol. 102, no. 5:1372-1385.

Eliade, Mircia (1954). The Myth of the Eternal Return or, Cosmos and History, Princeton, NJ: Princeton University Press.

Geertz, Clifford (1973). The Interpretation of Cultures, London: Fontana Press.

Grosse-Kracht, Klaus (1996). Gedächtnis und Geschichte: Maurice Halbwachs - Pierre Nora, in Geschichte, Wissenschaft und Unterricht, vol. 1:21-31.

Halbwachs, Maurice (1992). On Collective Memory, Edited \& Translated by L. A. Coser, Chicago: The University of Chicago Press.

Kierkegaard, Søren (1988 (1845)). Stages on Life's Way Princeton, NJ: Princeton University Press.

Klein, Kerwin Lee (2000). On the Emergence of Memory in Historical Discourse, Representations, no. 69, Winter:127-150.

Koselleck, Reinhardt (2003). Gedächtisstätten im Wandel, Der Blaue Reiter Journal für Philosophie, vol. 18, nr. 2:58-62.

Lincoln, Bruce (1989). Discourse and the Construction of Society Comparative Studies of Myth, Ritual, and Classification, Oxford: Oxford University Press.

Lincoln, Bruce (1999). Theorizing Myth - Narrative, Ideology, and Scholarship, Chicago: The University of Chicago Press.

Markovits, Andrei S. \& Reich, Simon (1997). The German Predicament Memory and Power in the new Europe, Ithaka, NY: Cornell University Press. 
Past and Future in the construction of Communal identity ...

Nora, Pierre (1989). Between Memory and History: Les Lieux de Memoire, Representations, no. 26, Spring:7-24.

Novick, Peter (1999). The Holocaust in American Life, Boston: Houghton Mifflin Company.

Ricoeur, Paul (1984). Time and Narrative, vol.1, Chicago: The University of Chicago Press.

Ricoeur, Paul (1988). Time and Narrative, vol. 3, Chicago: The University of Chicago Press.

Ricoeur, Paul, (1991). Narrative Identity, i: Philosophy Today, Spring 1991:7381.

Ricoeur, Paul (1992). Oneself as Another, Chicago: The University of Chicago Press.

Rüsen, Jörn (1994). Historische Orientierung - Über die Arbeit des Geschichtsbewusstseins, sich in der Zeit zurechtzufinden, Wien, Köln, Weimar: Böhlau Verlag.

Tudor, Henry (1978). Political myths and practical understanding, Pacific Quarterly, 3: 294-319.

Warring Anette (1996). Kollektiv erindring - et brugbart begreb? i: Bernard Eric Jensen, Carsten Tage Nielsen \& Torben Weinreich (red.), Erindringens og Glemslens politik, Roskilde: Roskilde Universitets Forlag:205-233.

Weinreich, Torben (1996). 'Som om det var igår' - den erindrende fortæller, i: Bernard Eric Jensen, Carsten Tage Nielsen \& Torben Weinreich (red.), Erindringens og Glemslens politik, Roskilde: Roskilde Universitets Forlag:85-106.

White, Hayden (1980). The Value of Narrativity in the Representation of Reality, Critical Inquiry, 7, 1:5-27.

Wilson, Robert A. (2005). Collective Memory, Group minds, and the extended mind thesis, Cognitive Processing, vol. 6 (4), December.

Young, James E. (1993). The Texture of Memory. Holocaust Memorials and Meaning, New Haven, CT: Yale University Press.

Zelizer, Barbie (1995). Reading the Past against the Grain; the Shape of Memory Studies, Critical Studies in Mass Communication, vol. 12:214239. 